\title{
ANGKA KEJADIAN KOMPLIKASI INTRAKRANIAL PADA PENDERITA HIV/AIDS YANG DI RAWAT INAP DI BAGIAN NEUROLOGI RSUP PROF. DR. R. D. KANDOU MANADO PERIODE JULI 2012 - JUNI 2013
}

\author{
Christy B. Tumbelaka \\ Denny J. Ngantung \\ J. Maja P. S \\ Bagian Neurologi Fakultas Kedokteran Universitas Sam Ratulangi Manado \\ Email: christy.tumbelaka@yahoo.com
}

\begin{abstract}
Human Immunodeficiency Virus (HIV) is virus that causes Acquired Immunodeficiency Syndrome (AIDS), which is a retrovirus disease that characterized by the severe immunosuppression that cause opportunistic infection, secondary neoplasm and neurologic manifestations. Nervous system involvement in HIV infections may occur directly through the virus and indirectly as a result of opportunistic infections due to immunocompromised. This study aimed to determine the incidence of intracranial complication in HIV/AIDS patients who were hospitalized in Neurology Ward of RSUP Prof. Dr. R. D. Kandou Manado from July 2012 to June 2013. This study were a retrospective descriptive study using medical record of patients with HIV/AIDS. The results showed there were 36 patients with HIV/AIDS and 27 patients had intracranial complications. Tuberculous Meningitis was the most common type of complications with percentage (51,9\%). Based on those 27 HIV/AIDS patients with intracranial complication, patients who were 25-34 years old (44\%) have the most intracranial complication. Based on the gender percentage, it is dominated by male $(59,3 \%)$ and based on the occupations, it is commonly came from entrepreneurs (29,6\%). Conclusion: The incidences of intracranial complication in patients with HIV/AIDS were quite high on Tuberculous Meningitis, and it is dominated by male. The highest distributions were found on aged 25-34 whose occupation were entrepreneurs.
\end{abstract}

Keywords: Intracranial Complication, HIV/AIDS, patients.

Abstrak: Human Immunodeficiency Virus (HIV) merupakan virus yang menyebabkan penyakit Acquired Immunodeficiency Syndrome (AIDS) yaitu suatu penyakit retrovirus yang ditandai dengan imunosupresi berat yang menimbulkan infeksi oportunistik, neoplasma sekunder, dan manifestasi neurologis. Keterlibatan sistem saraf pada infeksi HIV dapat terjadi secara langsung karena virus tersebut dan tidak langsung akibat infeksi oportunistik akibat imunokompromis. Penelitian ini bertujuan untuk mengetahui angka kejadian komplikasi intrakranial pada penderita HIV/AIDS yang di rawat inap di Bagian Neurologi RSUP Prof. Dr. R. D. Kandou Manado selama periode Juli 2012 - Juni 2013. Metode penelitian ini ialah deskriptif retrospektif dengan menggunakan catatan rekam medik penderita HIV/AIDS. Hasil peneitian memperlihatkan dari 36 pasien HIV/AIDS, terdapat 27 penderita yang memiliki komplikasi intrakranial dengan persentase jenis komplikasi intrakranial terbanyak yaitu Meningitis Tuberkulosis (51,9\%). Dari 27 penderita HIV/AIDS yang memiliki komplikasi intrakranial paling banyak ialah pada kelompok umur 25-34 tahun (44,4\%) sedangkan untuk jenis kelamin, didominasi oleh penderita 
berjenis kelamin laki-laki (59,3\%), dan jenis pekerjaan terbanyak ialah wiraswasta (29,6\%). Kesimpulan: Angka kejadian komplikasi intrakranial pada penderita HIV/AIDS yang cukup tinggi terdapat pada Meningitis Tuberkulosis dengan jenis kelamin terbanyak ialah laki-laki. Distribusi yang cukup tinggi pula ditemukan pada kelompok umur 25-34 tahun dengan jenis pekerjaan sebagai wiraswasta.

Kata Kunci: Komplikasi Intrakranial, HIV/AIDS, penderita

\section{PENDAHULUAN}

Penyakit infeksi Human Immunodeficiency Virus (HIV) dan Acquired Immune Deficiency Syndrome (AIDS) hingga kini masih merupakan masalah kesehatan global dengan tingginya angka kejadian dan kematian. ${ }^{1}$ HIV termasuk dalam famili Retroviridae, subfamili Lentivirinae adalah virus yang menyebabkan penyakit AIDS yaitu suatu penyakit retrovirus yang ditandai dengan imunosupresi berat yang menimbulkan infeksi oportunistik, neoplasma sekunder, dan manifestasi neurologis., 2,3

Pada tahun 2007, World Health Organization (WHO) memperkirakan bahwa 33.200.000 orang hidup dengan HIV/AIDS. Diperkirakan pada akhir tahun 2009, sudah 333.200 orang yang terinfeksi HIV/AIDS di Indonesia. Di provinsi Sulawesi Utara, kasus HIV/AIDS yang pertama kali dilaporkan pada tahun 1997 di Rumah Sakit Bethesda. Selang empat tahun terakhir terjadi peningkatan kasus yang cukup bermakna. Total kasus HIV/AIDS di provinsi Sulawesi Utara sampai akhir tahun 2008 adalah 456 kasus. Khusus untuk kota Manado 74 kasus HIV dan 103 kasus untuk penderita AIDS. Sebagian besar dari penderita HIV merupakan pemakai obat terlarang dengan jarum suntik. ${ }^{4,5}$

Keterlibatan sistem saraf pada infeksi HIV dapat terjadi secara langsung karena virus tersebut dan tidak langsung akibat infeksi oportunistik akibat imunokompromis. Studi di negara Barat melaporkan komplikasi sistem saraf terjadi pada 30\% - 70\% penderita HIV. HIV/AIDS dapat menyebabkan komplikasi intrakranial seperti Toksoplasmosis Otak (TO), Meningitis Tuberkulosis, Meningitis Kriptokokus, Demensia HIV, Leukoensefalopati multifokal progresif., Menurut data WHO diketahui sekitar 300 juta orang menderita toksoplasmosis. Penyakit ini dapat menyerang manusia dan berbagai jenis mamalia dan juga merupakan penyakit infeksi parasit yang paling sering terjadi pada manusia. ${ }^{7}$

Di Indonesia hampir 50\% kasus dalam stadium AIDS menderita tuberkulosis paru. Karena itu Meningitis TB selalu ada dalam diferensial diagnosis pasien AIDS dengan simptom susunan saraf pusat. Menurut WHO, data tahun 1997, diperkirakan TBC menyebabkan kematian lebih dari 1 juta penduduk di negara-negara Asia. Meningitis TBC lebih sering pada anak usia 04 tahun yang tinggal di daerah dengan prevalensi TBC tinggi. Sebaliknya di daerah dengan prevalensi TBC rendah, meningitis TBC lebih sering di jumpai pada orang dewasa. ${ }^{5}$

Di Indonesia, angka kejadian meningitis kriptokokus pada penderita HIV belum diketahui. Penelitian di Thailand melaporkan prevalensi kriptokokus pada penderita HIV sebesar $18,5 \%{ }^{6}$

Meningkatnya masalah pada sistem saraf yang terkait infeksi HIV/AIDS di negara berkembang termasuk Indonesia, mendorong penulis untuk melakukan penelitian mengenai angka kejadian komplikasi intrakranial pada penderita HIV yang di rawat inap di Bagian Neurologi RSUP Prof. Dr. R. D. Kandou Manado periode Juli 2012 - Juni 2013. 


\section{METODE PENELITIAN}

Penelitian ini ialah bersifat deskriptif dengan menggunakan metode retrospektif dan dilaksanakan di Bagian Neurologi RSUP Prof. Dr. R. D. Kandou Manado selama bulan November - Desember 2013. Populasi ialah semua pasien di Bagian Neurologi RSUP Prof. Dr. R. D. Kandou Manado periode Juli 2012 - Juni 2013. Subjek penelitian yaitu semua pasien HIV/AIDS yang di rawat inap di Bagian Neurologi RSUP Prof. Dr. R. D. Kandou Manado periode Juli 2012 - Juni 2013. Variabel penelitian yang dipakai ialah jenis komplikasi intrakranial, jenis kelamin, umur, dan pekerjaan.

\section{HASIL}

Berdasarkan hasil penelitian yang dilakukan secara retrospektif yakni dengan cara pengumpulan data (status dan catatan rekam medik) tentang HIV/AIDS yang di rawat inap di Bagian Neurologi RSUP Prof. Dr. R. D. Kandou Manado periode Juli 2012 - Juni 2013, diperoleh jumlah penderita HIV/AIDS sebanyak 36 pasien. Dari jumlah tersebut, tercatat sebanyak 27 penderita HIV/AIDS yang memiliki komplikasi intrakranial.

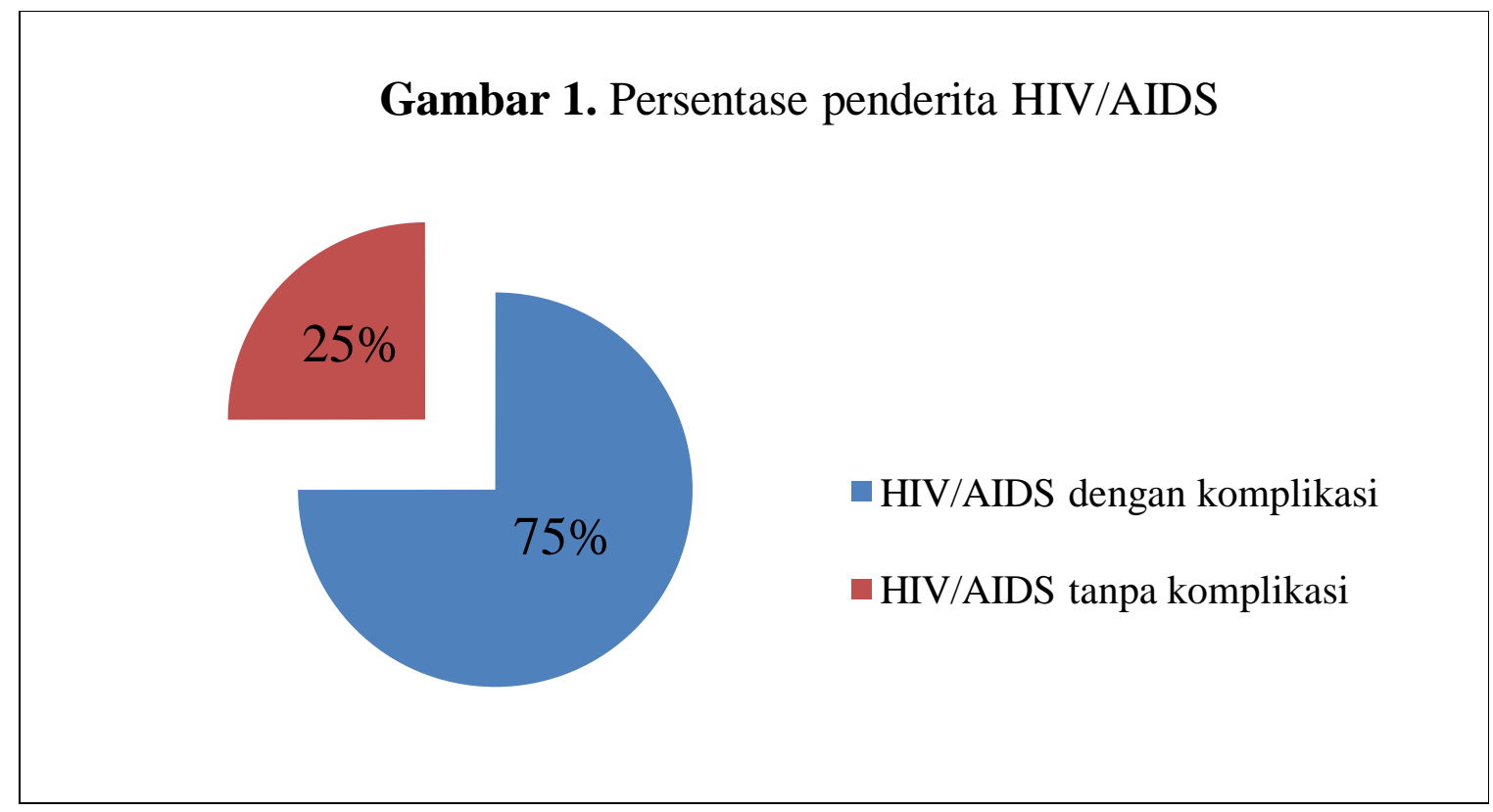

Menurut jenis komplikasi intrakranial HIV/AIDS, paling banyak ditemukan pada pasien dengan komplikasi Meningitis Tuberkulosis yaitu sebanyak 14 pasien (51,9\%) dan diikuti dengan Toksoplasmosis Otak sebanyak 10 pasien (37\%) dan Meningitis Kriptokokus sebanyak 3 pasien $(11,1 \%)$ dari seluruh data yang diperoleh. 
Tabel 1. Distribusi Penderita HIV/AIDS yang memiliki Komplikasi Intrakranial berdasarkan Jenis Komplikasi.

\begin{tabular}{ccc}
\hline \hline Jenis Komplikasi Intrakranial & Jumlah & $\begin{array}{c}\text { Persentase } \\
\text { (\%) }\end{array}$ \\
\hline Toksoplasmosis Otak & 10 & 37 \\
Meningitis Tuberkulosis & 14 & 51,9 \\
Meningitis Kriptokokus & 3 & 11,1 \\
Demensia HIV & 0 & 0 \\
Leukoensefalopati Multifokal & 0 & 0 \\
Progresif & & $\mathbf{1 0 0}$ \\
Total & $\mathbf{2 7}$ & $\mathbf{}$
\end{tabular}

Berdasarkan jenis kelamin, didapatkan jumlah pasien yang berjenis kelamin laki-laki lebih banyak dibandingkan perempuan, yaitu 16 pasien atau sebesar 59,3\%, sedangkan yang berjenis kelamin perempuan yaitu 11 pasien atau sebesar 40,7\% dari seluruh data yang diperoleh.

Tabel 2. Distribusi Penderita HIV/AIDS yang memiliki Komplikasi Intrakranial berdasarkan Jenis Kelamin.

\begin{tabular}{ccc}
\hline \hline Jenis Kelamin & Jumlah & $\begin{array}{c}\text { Persentase } \\
\text { (\%) }\end{array}$ \\
\hline Laki - Laki & 16 & 59,3 \\
Perempuan & 11 & 40,7 \\
Total & $\mathbf{2 7}$ & $\mathbf{1 0 0}$ \\
\hline \hline
\end{tabular}

Distribusi penderita HIV/AIDS dengan komplikasi intrakranial pada tahun 2012 - 2013 paling banyak terdapat pada kelompok umur 25 - 34 tahun sebanyak 12 pasien atau sebesar 44,4\%. Paling sedikit terdapat pada kelompok umur 55 - 64 tahun yaitu 2 pasien atau sebesar $7,4 \%$, dan yang kelompok umur $>65$ tahun tidak ditemukan.

Tabel 3. Distribusi Penderita HIV/AIDS yang memiliki Komplikasi Intrakranial berdasarkan Umur.

\begin{tabular}{ccc}
\hline \hline Umur & Jumlah & $\begin{array}{c}\text { Persentase } \\
(\mathbf{\%})\end{array}$ \\
\hline 15 - 24 tahun & 4 & 14,8 \\
25 - 34 tahun & 12 & 44,4 \\
35 - 44 tahun & 6 & 22,2 \\
45 - 54 tahun & 3 & 11,1 \\
55 - 64 tahun & 2 & 7,4 \\
65 - 74 tahun & 0 & 0 \\
$\geq$ 75 tahun & 0 & 0 \\
Total & $\mathbf{2 7}$ & $\mathbf{1 0 0}$ \\
\hline \hline
\end{tabular}


Berdasarkan jenis pekerjaan, pasien HIV/AIDS yang memiliki komplikasi intrakranial paling banyak ditemukan bekerja sebagai wiraswasta yaitu 8 pasien atau sebesar 29,6\% dari seluruh data yang diperoleh.

Tabel 4. Distribusi Penderita HIV/AIDS yang memiliki Komplikasi Intrakranial berdasarkan Pekerjaan.

\begin{tabular}{ccc}
\hline \hline Jenis Pekerjaan & Jumlah & $\begin{array}{c}\text { Persentase } \\
\mathbf{( \% )}\end{array}$ \\
\hline Pegawai Negeri Sipil (PNS) & 3 & 11,1 \\
Wiraswasta & 8 & 29,6 \\
Pelajar / Mahasiswa & 2 & 7,4 \\
Petani & 5 & 18,5 \\
Ibu Rumah Tangga (IRT) & 6 & 22,2 \\
Lain - lain & 3 & 11,1 \\
Total & $\mathbf{2 7}$ & $\mathbf{1 0 0}$ \\
\hline \hline
\end{tabular}

\section{BAHASAN}

Berdasarkan hasil penelitian mengenai angka kejadian komplikasi intrakranial pada penderita HIV/AIDS yang di rawat inap di Bagian Neurologi RSUP Prof. Dr. R. D. Kandou Manado periode juli 2012 - juni 2013, didapatkan sebanyak 36 pasien yang terdiagnosis HIV/AIDS. Dari jumlah tersebut, tercatat sebanyak 27 penderita HIV/AIDS yang memiliki komplikasi intrakranial, sehingga penelitian didasarkan pada data tersebut.

Berdasarkan jenis komplikasi intrakranial, didapatkan penderita dengan jenis komplikasi intrakranial Meningitis Tuberkulosis sebanyak 14 pasien (51,9\%). Jenis komplikasi ini lebih banyak dibandingkan dengan jenis komplikasi intrakranial lain yang didapatkan saat penelitian, Toksoplasmosis Otak sebanyak 10 pasien (37\%) dan Meningitis Kriptokokus sebanyak 3 pasien (11,1\%). Hal ini sesuai dengan kepustakaan yang menulis bahwa di Amerika Serikat, meningitis tuberkulosis ditemukan pada 32\% kasus meningitis. Di Indonesia hampir 50\% kasus dalam stadium AIDS menderita tuberkulosis paru, karena itu meningitis tuberkulosis selalu ada dalam diferensial diagnosis pasien AIDS. ${ }^{6,8}$

Jumlah pasien Meningitis Tuberkulosis di Indonesia merupakan ketiga terbanyak di dunia setelah India dan China. Hal ini berbeda dengan hasil penelitian di RSCM pada Januari 2007 September 2010, yang mengatakan bahwa Toksoplasmosis Otak merupakan kasus terbanyak yaitu sebesar 48,5\% dengan angka kematian sebesar 31,1\%. Insiden penyakit ini bervariasi dari satu tempat dengan tempat yang lain, hal ini bergantung pada keberadaan parasit Toxoplasma sebagai penyebabnya dan juga bergantung pada kebersihan daerah tersebut., ${ }^{5,6,8}$

Berdasarkan jenis kelamin, didapatkan data bahwa laki-laki lebih banyak menderita HIV/AIDS dengan komplikasi intrakranial dibandingkan perempuan, dengan distribusi laki-laki sebanyak 16 pasien (59,3\%) dan perempuan sebanyak 11 pasien (40,7\%). Hasil ini sama dengan hasil penelitian berdasarkan data Bidang Pengendalian Masalah Kesehatan (PMK) yang menyatakan bahwa jenis kelamin laki-laki lebih banyak dibandingkan perempuan, yaitu 762 kasus pada laki-laki dan 539 kasus pada perempuan. ${ }^{4}$ 
Faktor yang membuat angka HIV/AIDS rendah pada perempuan dikarenakan, perempuan lebih rajin menggunakan pengaman atau kondom dibandingkan laki-laki. Meskipun jumlah perempuan hingga saat ini lebih sedikit dibandingkan laki-laki, dampak pada perempuan akan selalu lebih besar. Penularan pada perempuan dapat berlanjut dengan penularan pada bayi jika terjadi kehamilan. Risiko penularan HIV dari ibu pengidap HIV ke bayinya berkisar 15-40\%. Bayi yang lahir dari seorang ibu pengidap HIV mungkin akan terinfeksi HIV sebelum, selama, atau sesudah proses kelahirannya. Penularan juga dapat terjadi melalui Air Susu Ibu (ASI). ${ }^{9}$

Dilihat dari hasil penelitian mengenai distribusi frekuensi umur penderita, didapatkan kelompok umur yang terbanyak menderita HIV/AIDS dengan komplikasi intrakranial adalah pada kelompok 25 - 34 tahun yaitu 12 pasien (44,4\%). Hal ini sama dengan data dari negara berkembang Afrika, yaitu 50\% orang dewasa hidup dengan HIV/AIDS pada tahun 2000. Sedangkan di Indonesia berdasarkan Dinas Kesehatan Provinsi Sulawesi Utara tahun 2008 menyatakan bahwa berdasarkan kelompok umur, penderita terutama berasal dari kelompok umur produktif yakni 20 - 29 tahun (50\%) dan 30 - 39 tahun (26\%). Hasil penelitian Bidang Pengendalian Masalah Kesehatan (PMK) menyatakan bahwa frekuensi terbanyak pada usia 20 29 tahun, yaitu 558 kasus dari total 1301 kasus. Penderita yang terkena, rata-rata usia produktif melalui narkoba suntik dan hubungan seksual yang tidak aman (tanpa menggunakan kondom)., ${ }^{2,9}$

Selain pendidikan seks yang kurang pada usia produktif, karena jumlah Lembaga Swadaya Masyarakat (LSM) terkait dengan jumlah masyarakat yang tidak sebanding. Akibatnya masyarakat kekurangan informasi yang benar akan hal ini. Diserangnya kelompok usia produktif ini merupakan satu hal yang perlu diperhatikan mengingat kelompok penduduk ini merupakan aset pembangunan bangsa. ${ }^{9}$

Berdasarkan jenis pekerjaan, yang terbanyak menderita HIV/AIDS komplikasi intrakranial adalah wiraswasta yaitu 8 pasien (29,6\%). Terdapat sebanyak 6 pasien $(22,2 \%)$ yang memiliki pekerjaan sebagai Ibu Rumah Tangga (IRT), petani sebanyak 5 pasien (18,5\%), Pegawai Negeri Sipil (PNS) sebanyak 3 pasien (11,1), pelajar/mahasiswa sebanyak 2 pasien $(7,4 \%)$ dan yang tidak diketahui berjumlah 3 pasien $(11,1)$. Penelitian ini sama dengan hasil laporan penelitian yang dilakukan oleh Kementerian Kesehatan RI pada tahun 1987 - Maret 2013 yang mengatakan bahwa jenis pekerjaan wiraswasta merupakan jenis pekerjaan terbanyak, yaitu sebanyak 46,4\% atau sebanyak 13.211 penderita. $^{10}$

\section{KESIMPULAN}

Berdasarkan penelitian yang telah dilakukan dapat disimpulkan bahwa angka kejadian komplikasi intrakranial pada penderita HIV/AIDS yang cukup tinggi terdapat pada Meningitis Tuberkulosis dengan jenis kelamin terbanyak ialah laki-laki. Distribusi yang cukup tinggi pula ditemukan pada kelompok umur 25-34 tahun dengan jenis pekerjaan sebagai wiraswasta.

\section{SARAN}

Penting untuk dilakukan upaya-upaya mengurangi jumlah angka kejadian penderita HIV/AIDS, misalnya dengan melakukan penyuluhan kepada masyarakat guna untuk meningkatkan pengetahuan tentang pengenalan gejala dini ancaman HIV/AIDS, dan juga perlu dilakukan penelitian selanjutnya pada populasi yang lebih besar, untuk mendapatkan data prevalensi yang lebih lengkap. 


\section{DAFTAR PUSTAKA}

1. Nasronudin. Penatalaksanaan Klinis Infeksi HIV \& AIDS. Barakbah J, Soewandojo E, Suharto, Hadi S, Astuti WD. HIV \& AIDS Pendekatam Biologi Molekuler, Klinis dan Sosial. Edisi Pertama. Surabaya: Airlangga University Press: 2007. h. 31-44.

2. Mitchell RN, Kumar V. Penyakit Imunitas. Kumar V, Cotran R, Robbins S. Patologi. Edisi Ketujuh. Jakarta: EGC; 2004. h.113-184.

3. Nasronudin. Dasar Virologi dan Infeksi HIV. Barakbah J, Soewandojo E, Suharto, Hadi S, Astuti WD. HIV \& AIDS Pendekatam Biologi Molekuler, Klinis dan Sosial. Edisi Pertama. Surabaya: Airlangga University Press: 2007. h. 1-10.

4. Dinas Kesehatan Provinsi Sulawesi Utara. Profil Kesehatan Provinsi Sulawesi Utara 2008. Edisi Pertama. Manado: Sulut Sehat 2010; 2009. h. 11-30.

5. Kasper LH. Toxoplasma infections. In: Fauci AS, Braunwald D, Kasper DL, Harrison’s Principles Of Internal Medicine $17^{\text {th }}$ ed New York: McGraw-Hill Companies. Inc. 2008. P 1305-1311.

6. Imran D. NEURO-AIDS. Sudewi AAR, Sugianto P, Ritarwan K. Infeksi pada Sistem Saraf. Edisi Pertama. Surabaya: Pusat Penerbitan dan Percetakan Unair; 2011. h. 63-74.

7. Kurniawan. Tiga ratus juta orang terkena toksoplasmosis. 2009. Avaible from: http://us.health.detik.com/read/2009/08/06/163531/1178719/763/300[Accesed: $\quad 6$ September 2013].

8. Frida M. Meningitis Tuberkulosis. Dalam: Sudewi AAR, Sugianto P, Ritarwan K. Infeksi pada sistem saraf. Kelompok Studi Neuro Infeksi PERDOSSI. Surabaya. Airlangga University Press. 2011; hal. 13-21.

9. Bob S. Analisis epidemiologi. Sunaryadi, Sugito, Fetty I. Situasi HIV/AIDS di Indonesia tahun 1987-2006. Edisi pertama. Jakarta: Pusat Data Informasi Departemen Kesehatan R. I; 2006. hal. 20-29.

10. Kementerian Kesehatan RI. Perkembangan HIV/AIDS Triwulan I Tahun 2013. Jakarta 2013. Hal. 2. 